\title{
Numerical taxonomic analysis of imperfect yeast species in Candida and Torulopsis shows no basis for generic separation
}

\author{
F. C. OdDs, ${ }^{*} \dagger$ M. J. SACKIN and DoRothY JoNES \\ Department of Microbiology, University of Leicester, PO Box 138, University Road, Leicester LEI 9HN, UK
}

(Received 3 November 1989; revised 3 January 1990; accepted 15 January 1990)

\begin{abstract}
A numerical taxonomic analysis was performed on 79 phenotypic characters of 147 imperfect yeast species currently assigned to the genus Candida. The characters used were drawn from two monographs on yeast taxonomy. The analysis revealed 10 clusters of three or more species that were similar at the level of $75 \%$ or more, and seven clusters containing only one or two species. None of the 10 major clusters contained exclusively species that were traditionally assigned to the genus Torulopsis, while the 12 Candida species of basidiomycetous affinity fell into three clusters with only one species of ascomycetous affinity included. Statistical determination of the five most important differential characters for each cluster failed to show the property of pseudomycelium/mycelium formation as significant for any cluster. The study provides no evidence to support a distinction between taxa that were formerly divided between the genera Candida and Torulopsis and supports previous proposals that these genera should be fused.
\end{abstract}

\section{Introduction}

The taxonomy of some yeasts that do not form perfect (sexual) stages is controversial. The great majority of imperfect yeasts that have no distinctive morphological characteristics were traditionally assigned to one of four genera-Candida, Cryptococcus, Rhodotorula or Torulopsis. However, van Uden \& Buckley (1970) considered that the traditional criterion for separation of Candida and Torulopsis, production and non-production of pseudohyphae, was 'arbitrary and artificial' and suggested that '... it appears logical to classify the group as one single huge artificial genus from which natural taxa could be split off in the future whenever sufficient information should become available.'

A formal proposal to merge the genus Candida with the genus Torulopsis was made in 1978 by Yarrow \& Meyer, and two major monographs on yeast taxonomy subsequently accepted this revised diagnosis of the genus Candida (Barnett et al., 1983; Kreger-van Rij, 1984). However, the taxonomic fusion of this yeast group into a single genus has been strenuously opposed by McGinnis (1980) and McGinnis et al. (1984), and several authors and editors continue to distinguish between Torulopsis and Candida species in their publications.

Such a confused state of affairs is neither constructive

$\dagger$ Present address: Laboratory of Bacteriology and Mycology, Janssen Pharmaceutica, Turnhoutseweg 30, B-2340 Beerse, Belgium. nor desirable. Opposition to the taxonomic union of Candida and Torulopsis appears to come principally from medical mycologists, who commonly encounter only one species previously assigned to the genus Torulopsis, i.e. $T$. glabrata, which happens to be very readily distinguishable from the Candida species encountered in medical practice. However, Candida and Torulopsis species commonly isolated from clinical material account for only about $5 \%$ of all the species recognized in the Candida-Torulopsis group (Ahearn \& Schlitzer, 1984; Meyer et al., 1984), so consideration of only the medically important species is a scientifically inadequate basis for judging the taxonomic validity of a generic grouping.

The present study was undertaken to examine whether a numerical taxonomic analysis of imperfect species assigned to the Candida-Torulopsis group might reveal any grouping of taxa that would reinforce the traditional two-genus classification of these yeasts. The study is concerned only with the taxonomic problem - the complicated question of nomenclature of genera, where there are arguments for and against the precedence of the name Torulopsis over Candida (Yarrow \& Meyer, 1978; McGinnis et al., 1984) is beyond the scope of the present communication.

\section{Methods}

Species included. Two monographs were used as reference sources to determine the imperfect species included in the analysis. Only the 147 
Table 1. Clusters of Candida species with phenotypic similarities of $75 \%$ or more and the five characters most distinctive for each cluster

Only species without known teleomorphs and accepted by both Barnett et al. (1983) and Meyer et al. (1984) were included in the study. All are listed here as Candida species in conformity with those two sources. $(T)$ indicates a species formerly listed in the genus Torulopsis by van Uden \& Buckley (1970) or newly described as a Torulopsis sp. subsequent to that publication. An asterisk indicates a species of basidiomycetous affinity.

\begin{tabular}{|c|c|c|}
\hline Cluster & Species included & Most definitive tests $\dagger$ \\
\hline 1 & $\begin{array}{l}\text { aaseri, atmosphaerica, buinensis, butyri, chilensis, dendronema, diddensiae, entomaea, } \\
\text { entomophila, ergatensis, friedrichii, homilentoma, insectorum, ishiwadae, membranaefaciens, } \\
\text { naeodendra, peltata }(T), \text { polymorpha, silvanorum, silvicultrix, terebra, veronae }\end{array}$ & $\begin{array}{l}\text { Maltose growth }(+) \\
\text { Cellobiose growth }(+) \\
\text { Sucrose growth }(+) \\
\text { D-Xylose growth }(+) \\
\text { Cadaverine growth }(+)\end{array}$ \\
\hline 2 & blankii, chiropterorum, edax, hellenica, hydrocarbofumarica, inositophila, steatolytica & $\begin{array}{l}\text { myo-Inositol growth }(+) \\
\text { Growth at } 37^{\circ} \mathrm{C}(+) \\
\text { L-Arabinose growth }(+) \\
\text { L-Sorbose growth }(+) \\
0.01 \% \text { cycloheximide growth }(+)\end{array}$ \\
\hline 3 & auringiensis, succiphila & \\
\hline 4 & $\begin{array}{l}\text { albicans, azyma }(T), \text { fennica, fuviatilis, freyschussii, fructus }(T), \text { glaebosa, incommunis, } \\
\text { insectamans, intermedia, kruisii }(T), \text { maltosa, maritima, melibiosica, mesenterica, } \\
\text { multis-gemmis }(T), \text { musae }(T), \text { oleophila, oregonensis, parapsilosis, rhagii, pseudointermedia, } \\
\text { quercitrusa, quercuum, sake, solani, suecica, tenuis, tepae, tropicalis, vartiovaarai, viswanathii, } \\
\text { xestobii }\end{array}$ & $\begin{array}{l}\text { D-Glucuronate growth }(-) \\
\text { Urea hydrolysis }(-) \\
\text { Diazonium blue B reaction }(-) \\
\text { Methanol growth }(-) \\
\text { Growth without pantothenate }(+)\end{array}$ \\
\hline 5 & $\begin{array}{l}\text { anatomiae }(T), \text { beechii, boleticola, cacaoi, cantarelli }(T), \text { conglobata, ernobii }(T), \text { krissii, } \\
\text { santamariae, savonica, schatavii }(T), \text { torresii }(T), \text { zeylanoides }\end{array}$ & $\begin{array}{l}\text { Melezitose growth }(-) \\
\text { Sucrose fermentation }(-) \\
\text { Raffinose growth }(-) \\
\text { Nitrate growth }(-) \\
\text { Maltose fermentation }(-)\end{array}$ \\
\hline 6 & haemulonii $(T), \operatorname{mogii}(T)$ & \\
\hline 7 & $\begin{array}{l}\text { boidinii, cariosilignicola, methanosorba }(T), \text { nemodendra }(T), \text { nitratophila }(T), \text { pignaliae }(T) \text {, } \\
\text { pinus }(T), \text { sonorensis }(T), \text { wickerhamii }(T)\end{array}$ & $\begin{array}{l}0.01 \% \text { cycloheximide growth }(+) \\
\text { Maltose growth }(-) \\
50 \% \text { glucose growth }(-) \\
\text { Melezitose growth }(-) \\
\text { Methyl } \alpha \text {-D-glucoside growth }(-)\end{array}$ \\
\hline 8 & spandovensis $(T)$, vanderwaltii $(T)$ & \\
\hline 9 & mucilagina & \\
\hline 10 & halophila, mannitofaciens $(T)$, versatilis $(T)$ & $\begin{array}{l}60 \% \text { glucose growth }(+) \\
\text { D-Glucitol growth }(-) \\
\text { Nitrate growth }(+) \\
\text { Nitrite growth }(+) \\
50 \% \text { glucose growth }(+)\end{array}$ \\
\hline 11 & $\begin{array}{l}\text { apicola }(T), \text { apis }(T), \text { austromarina }(T), \text {, berthetii, bombi, bombicola }(T), \text { castellii }(T), \text { catenulata, } \\
\text { dendrica }(T), \text { diversa, etchellsii }(T), \text { geochares, glabrata }(T), \text { gropengiesseri }(T), \text { halonitrophila } \\
(T), \text { humilis }(T), \text { hylophila, inconspicua }(T), \text { insectalens }(T), \text { karawaiewii }(T) \text {, lactis-condensis } \\
(T), \text { magnoliae }(T), \text { maris }(T), \text { milleri, nodaensis }(T), \text { norvegica }(T), \text { pararugosa, } \\
\text { rugopelliculosa, rugosa, silvae, silvatica }(T), \text { sorbophila }(T), \text { sorboxylosa, stellata }(T), \\
\text { tannotolerans }(T), \text { vinaria, vini }\end{array}$ & $\begin{array}{l}\text { Melezitose growth }(-) \\
\text { Methyl } \alpha \text {-D-glucoside growth }(-) \\
\text { Erythritol growth }(-) \\
\text { Cellobiose fermentation }(-) \\
\text { Lactose growth }(-)\end{array}$ \\
\hline 12 & auricularae $^{*}(T)$, foliorum ${ }^{*}$, philyla* $(T)$, psychrophila $(T)$, pustula* $(T)$, sonckii ${ }^{*}$ & $\begin{array}{l}\text { Glucose fermentation }(-) \\
\text { Growth at } 35^{\circ} \mathrm{C}(-) \\
\text { 2-Ketogluconate }(+) \\
\text { Methyl } \alpha \text {-D-glucoside growth }(-) \\
\text { Growth at } 37^{\circ} \mathrm{C}(-)\end{array}$ \\
\hline 13 & buffonii & \\
\hline 14 & antarctica $^{*}$, bacarum $^{*}(T)$, fragariorum ${ }^{*}(T)$, graminis $^{*}$, tsukubaensis $^{*}$ & $\begin{array}{l}\text { Diazonium blue } B \text { reaction }(+) \\
\text { Urea hydrolysis }(+) \\
\text { Nitrate growth }(+) \\
\text { Nitrite growth }(+) \\
\text { Growth without biotin }(+)\end{array}$ \\
\hline 15 & valdiviana & \\
\hline 16 & aquatica $^{*}$, curiosa $^{*}$ & \\
\hline 17 & salmanticensis & \\
\hline
\end{tabular}


species accepted by both Barnett et al. (1983) and Meyer et al. (1984) as members of the genus Candida without known teleomorphs were selected for study. This particular selection (Table 1) was made for two main reasons. First, it includes a good selection of imperfect species that were previously classified in the genera Candida or Torulopsis; second, it ensures that species already known to be the topic of controversy between yeast taxonomists were excluded. Species with known teleomorphic states or which are indistinguishable from known perfect species were excluded, since the problems of the taxonomy of Candida and Torulopsis are related only to species without known. perfect affinities. The selection inevitably excludes new Candida species that have been described since 1984 and it includes species of basidiomycetous as well as ascomycetous affinities. Weijman et al. (1988) have reclassified Candida species with basidiomycetous affinities in the genera Rhodotorula and Cryptococcus, but this reclassification was ignored for the purposes of the present study so that the basidiomycetous Candida species could act as an internal control for the ability of the numerical analysis to indicate valid sub-groupings within the genus.

A species is listed in Table 1 as a former member of the genus Torulopsis either if it was so classified by van Uden \& Vidal-Leiria (1970) or if it was a new species assigned to the genus Torulopsis subsequent to the publication of van Uden \& Vidal-Leiria (1970).

Designation of characters. The phenotypic characters used for the numerical analysis were principally those tabulated for the genus Candida by Barnett et al. (1983). Of these 83 characters, five were not used because they were consistently negative (inulin fermentation, acetic acid production), consistently positive (growth without folate, growth without $p$-aminobenzoate) or largely unknown (5-ketogluconate growth) for all the species involved. The remaining 78 characters taken from the data of Barnett et al. (1983) were scored as follows: negative $=$ 0 , variable $=1$, weak positive $=2$, delayed positive $=3$, positive $=4$. The property of pseudomycelium/mycelium formation was determined for each species according to the descriptions given by Meyer $e t$ al. (1984). These descriptions were interpreted according to the following scheme: no evidence of pseudomycelium formation among any strains in a species was scored as 0; pseudohyphae described as 'rudimentary', 'sparse', 'chains of roundish cells' and similar indications of minimal pseudohypha formation by some strains in a species were scored as 1 ; unequivocal formation of pseudohyphae by at least some strains in a species was scored 2; and formation of true hyphae by at least some strains in a species was scored 3 . Thus a total of 79 characters was used for the numerical analysis.

Because the property of pseudohypha/hypha formation was traditionally significant in differentiating Candida and Torulopsis species, the scores for each species obtained from the descriptions of Meyer $e t$ al. (1984) were compared with those derived in a blinded fashion from the descriptions in Barnett et al. (1983) as a means of checking their validity. Perfect agreement of the scores was found for 120 of the 147 species. For all the remaining 27 species, the pseudomycelium/mycelium score differed by only 1 , and in 13 of these cases the difference arose because more species are regarded by Barnett $e$ t al. (1983) as capable of true hypha formation (scoring 3 instead of 2) than are so regarded by Meyer et al. (1984). The scores used in the analysis were therefore considered as fair a representation as possible of the morphological capabilities of each species analysed.

Numerical taxonomy. A cluster analysis was performed on the taxa according to methods described by Sneath \& Sokal (1973). Gower's similarity coefficient (Gower, 1971) was calculated for all pairs of species and a dendrogram was drawn on the basis of unweighted average linkage between species. Groups of species with a similarity of $75 \%$ or better were regarded as homogeneous clusters. For each of these clusters, the most significant characters were determined by an algorithm developed from the CLUSTAN computer program (D. L.
Wishart). For each character and each cluster, two figures were calculated: $F$ (variance of character in cluster/variance of character over all species) and $T$ (cluster mean score for character minus overall mean score for character/overall standard deviation). A value of zerc for $F$ indicates homogeneity of a character within a cluster, while? serves as a measure of the deviation of the cluster mean for a character from the mean for all the species involved. This permits identification of the test characters that are most distinctive for a given cluster - they are the characters with the largest value of $T$ when $F=0$.

\section{Results}

The average-linkage dendrogram (Fig. 1) shows that the 147 Candida species analysed grouped into seven clusters at a similarity level $\left(\% S_{\mathrm{G}}\right)$ of 70 , and 17 clusters at a similarity level of $75 \% S_{\mathrm{G}}$. Seven of the latter clusters contained only one or two species. The species $C$. salmanticensis (cluster 17) was markedly different from all the others, showing an average similarity of only $58 \%$ to all the other 146 species analysed.

The 12 Candida species of basidiomycetous affinity appeared together in three separate clusters with $75 \%$ or greater similarity. C. psychrophila was the only species of presumed ascomycetous affinity to appear within these three clusters. The presumptively ascomycetous species C. valdiviana was $72 \%$ similar to two of the clusters of basidiomycetous species.

None of the species previously included in the genus Torulopsis emerged as a homogeneous cluster except for clusters 6 and 8, each of which contained only two species. At least one example of a Torulopsis species appeared in all clusters except 2, 3, 9, 13, 15, 16 and 17 , most of which included only one or two taxa. The majority of species in clusters 7,11 and 12 are former members of the genus Torulopsis. Table 1 lists the species in all the clusters together with the five most definitive characters for each cluster with three or more members, as determined from the values of $F$ and $T$ calculated for each character within each cluster. The property of pseudomycelium formation did not appear as a strongly definitive character for any of the clusters.

The medically important species $C$. albicans, $C$. parapsilosis and $C$. tropicalis were all found together in cluster 4, together with species such as $C$. intermedia and C. viswanathii, which occur rarely in clinical material (Odds, 1988). C. albicans and C. tropicalis in particular showed considerable similarity - better than $90 \%$ - in this analysis. C. glabrata, another clinically important yeast, fell within cluster 11 and thus showed less than $70 \%$ phenotypic similarity with the other medically important species. 


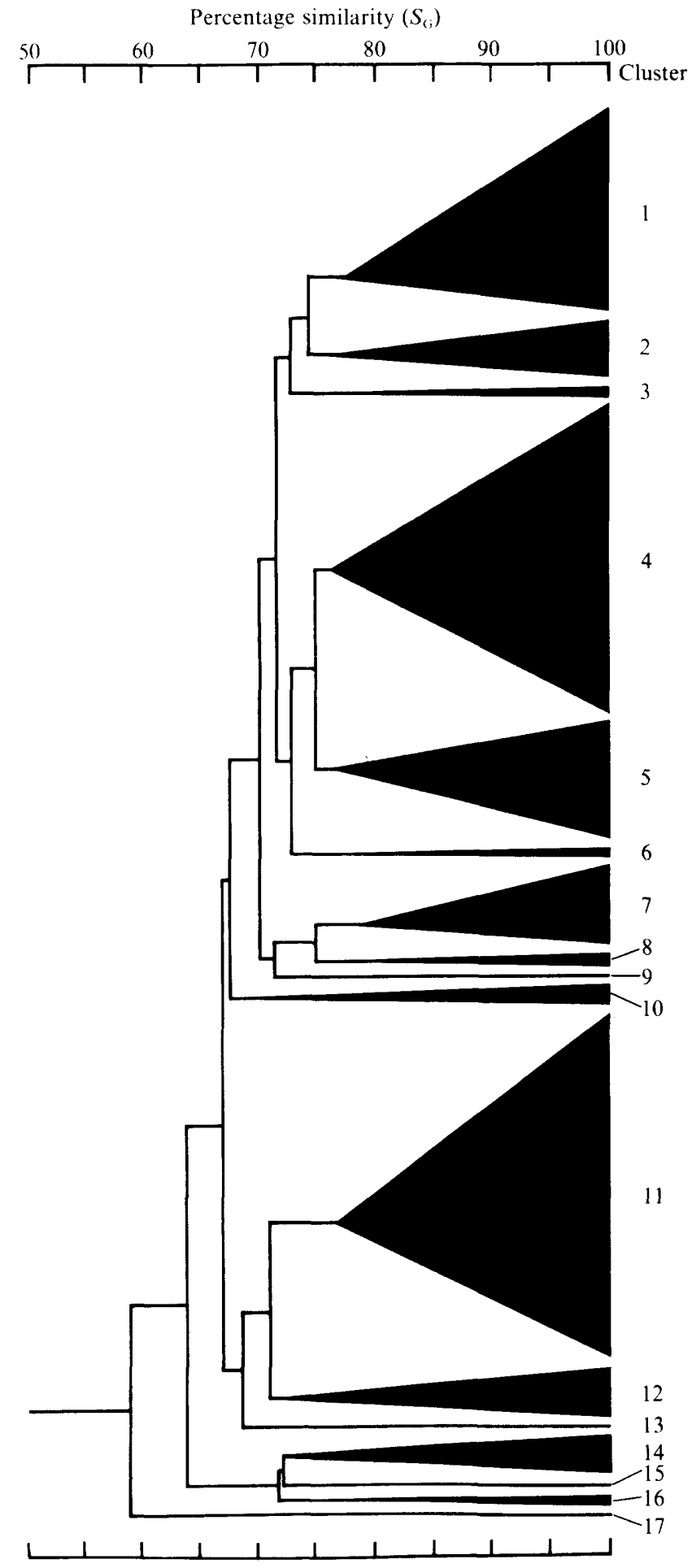

Fig. 1. Simplified dendrogram showing clusters obtained with $S_{\mathrm{G}}$ coefficient and unweighted average linkage clustering.

\section{Discussion}

The basis for separation of the genera Candida and Torulopsis, as previously circumscribed, was a single characteristic: formation or non-formation of pseudomycelium. In fact, the traditional definitions of the two genera allowed for the possibility of some overlap with respect to this character: for Candida the description given by van Uden \& Buckley (1970) was 'Pseudomycelium formation by all or most strains of all species and varieties,' while for Torulopsis the equivalent definition was 'Pseudomycelium absent or rudimentary' (van Uden \& Vidal-Leiria, 1970). Our numerical taxonomic analysis of imperfect species in the two genera shows that species previously classified in the genus Torulopsis do not fall into homogeneous clusters on the basis of their phenotypic properties, and that the property of pseudomycelium/ mycelium formation is not a strongly definitive phenotypic character for the demarcation of any of the clusters of species studied.

Viljoen \& Kock (1989) recently examined the taxonomy of the genus Candida on the basis of new data concerning fatty acid composition and electrophoretic karyotype and historical information on other properties of the species. Unlike us, they excluded species with basidiomycetous affinities from their analysis, and they included species with known teleomorphs as well as imperfect species. Their results, like ours, revealed no tendency for Torulopsis and Candida species to fall into objectively separable taxa. Because the selection of Candida species examined by Viljoen \& Kock (1989) does not correspond with ours we cannot directly compare the taxonomic groupings obtained in the two studies.

From our observations and from those of Viljoen \& Kock (1989), we agree with van Uden \& Buckley (1970), Yarrow \& Meyer (1978) and Ahearn (1983) that the distinction between Candida and Torulopsis has no scientific basis. McGinnis et al. (1984) argue that rudimentary pseudomycelium formation by Torulopsis species is normally easy to differentiate from the pseudomycelium formed by Candida species. However, they accept that occasional yeast isolates may be difficult to differentiate on this basis, and they point out that no taxonomic system can always unequivocally differentiate all taxa. We think this argument understates the extent to which pseudomycelium formation fails to serve as a criterion for generic differentiation of yeasts in practice.

Of the 147 imperfect yeast species included in the present study, 94 were classified in the genus Candida in 1970 (van Uden \& Buckley, 1970) or were newly described as Candida species after that date. Of these 94, four had originally been described as Torulopsis species because their discoverers found they made no pseudomycelium, but were subsequently reclassified as pseudomycelium-forming Candida species. A further eight of the 94 Candida species have been classified as Torulopsis 
species at some stage in their history, according to the lists of their synonyms given by Meyer et al. (1984). Thus, some $12 \%$ of species assigned to the genus Candida have been the source of confusion concerning their ability or inability to form pseudomycelium.

McGinnis et al. (1984) argue that the definition of the genus Candida proposed by Yarrow \& Meyer (1978) is so equivocal as to allow inclusion of members of the genera Cryptococcus and Rhodotorula. This implies that the latter genera were previously very clearly demarcated from Candida and Torulopsis: yet consideration of the histories of many Candida, Cryptococcus, Rhodotorula and Torulopsis species as described in the monograph edited by Lodder (1970) shows that confusion between these genera is by no means uncommon. Varieties of the species accepted as Cryp. laurentii in Lodder (1970) had been variously classified in all four genera by different authors, while $R h$. rubra and T. candida had historical synonyms in three of the four genera. The current relative positions of the genera Cryptococcus and Rhodotorula have been greatly strengthened by their redefinition to include basidiomycetous members of the genus Candida (including former members of the genus Torulopsis) (von Arx \& Weijman, 1979; Weijman et al., 1988). The exclusive restriction of Cryptococcus and Rhodotorula to imperfect yeasts of basidiomycetous affinity should greatly reduce the possibility of their confusion with the genus Candida.

A final argument against the traditional separation of Candida and Torulopsis arises from consideration of those species for which associations with perfect states have been demonstrated. van Uden \& Buckley (1970) mentioned that the species $C$. macedoniensis, C. pseudotropicalis and $T$. sphaerica all had perfect-state equivalents in the genus Kluyveromyces, while T. molischiana and several Candida species had perfect-state equivalents in the genus Hansenula. The latest monograph on the genus Kluyveromyces (van der Walt \& Johannsen, 1984) lists the single ascosporogenous species $K$. marxianus as having as imperfect forms $C$. kefyr and $C$. sphaerica: the latter was originally a Torulopsis, not a Candida species. If imperfect yeasts have teleomorphic equivalents in a single ascosporogenous species there seems to be little logic in retaining generic separation for the anamorphs.

We believe the continued separation of imperfect yeasts of the Candida-Torulopsis type into two genera is now taxonomically invalid not only because it is thought to be 'arbitrary and artificial' (van Uden \& Buckley, 1970) but it is also contrary to the evidence of our study. The issue of nomenclature of a single genus within the present definitions of the genus Candida (Yarrow \& Meyer, 1978; Barnett et al., 1983; Meyer et al., 1984; Weijman et al., 1988) is one we regard as controversial.
McGinnis (1980) and McGinnis et al. (1984) provide a strong case for precedence of the name 'Torulopsis' over 'Candida'. Yet 'Candida' is recommended over 'Torulopsis' in two major monographs of yeast taxonomy and nomenclature (Barnett et al., 1983; Kreger-van Rij, 1984). The eventual resolution of this problem will depend on cooperative adjudication within the rules of the International Code of Botanical Nomenclature.

\section{References}

AHEARN, D. G. (1983). The Yeasts. In Fungi Pathogenic for Humans and Animals, part A, pp. 73-79. Edited by D. H. Howard. New York: Marcel Dekker.

AHEARN, D. G. \& SCHLITZER, R. L. (1984). Key to yeasts pathogenic for man and animal. In The Yeasts : a Taxonomic Study, 3rd edn, pp. 998 1005. Edited by N. J. W. Kreger-van Rij. Amsterdam: Elsevier.

von ARX, J. A. \& Wiejman, A. C. M. (1979). Conidiation and carbohydrate composition in some Candida and Torulopsis species. Antonie van Leeuwenhoek 45, 547-555.

Barnett, J. A., Payne, R. W. \& Yarrow, D. (1983). Yeasts: Characteristics and Identification. Cambridge: Cambridge University Press.

GowER, J. K. (1971). A general coefficient of similarity and some of its properties. Biometrics 27, 857-871.

LODDER, J. (1970). The Yeasts: a Taxonomic Study, 2nd edn. Amsterdam: North Holland.

KREGER-VAN Ru, N. J. W. (1984). The Yeasts : a Taxonomic Study, 3rd edn. Amsterdam: Elsevier.

McGinnis, M. R. (1980). Recent taxonomic developments and changes in medical mycology. Annual Review of Microbiology 34, 109-135.

McGinnis, M. R., Ajello, L., Beneke, E. S., Drouhet, E., Goodman, N. L., Halde, C. J., Haley, L. D., Kane, J., Land, G. A., Padhye, A. A., Pincus, D. H., Rinaldi, M. G., Rogers, A. L., Salkin, I. F., Schell, W. A. \& Weitzman, I. (1984). Taxonomic and nomenclatural evaluation of the genera Candida and Torulopsis. Journal of Clinical Microbiology 20, 813-814.

Meyer, S. A., Ahearn, D. G. \& Yarrow, D. (1984). The genus Candida Berkhout. In The Yeasts: a Taxonomic Study, 3rd edn, pp. 585-844. Edited by N. J. W. Kreger-van Rij. Amsterdam: Elsevier.

Opds, F. C. (1988). Candida and Candidosis, 2nd edn. London : BaillièreTindall.

SNeath, P. H. A. \& Sokal, R. R. (1973). Numerical Taxonomy. San Francisco: W. R. Freeman \& Co.

vaN UdEN, N. \& BUCKLEY, H. (1970). Candida Berkhout. In The Yeasts: a Taxonomic Study, 2nd edn, pp. 893-1087. Edited by J. Lodder. Amsterdam: North Holland.

VAN Uden, N. \& VIDAL-LeIRIA, M. (1970). Torulopsis Berlese. In The Yeasts: a Taxonomic Study, 2nd edn, pp. 1235-1308. Edited by J. Lodder. Amsterdam: North Holland.

Viljoen, B. C. \& Kock, J. L. F. (1989). A taxonomic study of the yeast genus Candida Berkhout. Systematic and Applied Microbiology 12, 91-102.

VAN DER WALT, J. P. \& JohanNSEN, E. (1984). Kluyveromyces van der Walt emend. van der Walt. In The Yeasts: a Taxonomic Study, 3rd $e d n$, pp. 224-251. Edited by N. J. W. Kreger-van Rij. Amsterdam: Elsevier.

Weijman, A. C. M., Rodrigues de Miranda, L. \& van der Walt, J. P. (1988). Redefinition of Candida Berkhout and the consequent emendation of Cryptococcus Kützing and Rhodotorula Harrison. Antonie van Leeuwenhoek 54, 545-554.

YarRow, D. \& MeYer, S. A. (1978). Proposal for amendment of the diagnosis of the genus Candida Berkhout nom. cons. International Journal of Systematic Bacteriology 28, 611-615. 